Археология

УДК 903.53

ББК 63.48

DOI 10.31554/2222-9175-2021-42-9-18

М. С. Мищенкова

СКОПАЕНИЯ КУРГАНОВ (кофун-гун) В РЕГИОНЕ КИНКИ (остров Хонсю, Япония)

В статье рассматриваются основные скопления японских курганов (кофун) на территории региона Кинки (Кансай). Исследуются размеры и характер скоплений в каждой из префектур, входящих в регион Кинки, а также особенности форм и оформления отдельных курганов, погребального инвентаря в отдельных частях региона Кансай. Особое внимание уделяется кофун-гун в префектурах Осака и Нара, которые территориально сопоставимы с центром древнеяпонского государства Ямато.

Ключевые слова: кофун, курганы, древняя Япония, захоронения японских императоров, железный век.

\title{
M. S. Mishchenkova \\ CLUSTERS OF BURIAL MOUNDS (kofun-gun) \\ IN THE KINKI REGION (Honsu, island, Japan)
}

The article examines the main clusters of Japanese mounds (kofun) in the Kinki (Kansai) region. The size and nature of the clusters in each of the prefectures in the Kinki region, as well as the features of the forms and design of individual burial mounds, burial items in certain parts of the Kansai region are investigated. Particular attention is paid to kofun-gun in the prefectures of Osaka and Nara, which are geographically comparable to the center of the ancient Japanese state of Yamato.

Keywords: kofun, burial mounds, ancient Japan, burials of Japanese emperors, the Iron Age.

Кофун - это захоронения курганного типа, которые были распространены на японских островах в III-VII вв. н. э. Кофун могли иметь как небольшие, так и поистине колоссальные размеры в зависимости от социального положения захороненных в них людей. В наиболее крупных кофун, имеющих форму «замочной скважины», хоронили императоров Японии и членов их семьи. Именно в кофун этой необычной формы, дзэнпо:ко:энфун, характерной только для японских островов, ученые-археологи находят наиболее богатый погребальный инвентарь, который помогает исследователям определить степень социально-экономического и политического развития Японии в III-VII вв. н. э. [Кофун дзидай-но кэнкю: 1992: 5-7].

Кинки (другое название Кансай) - регион Японии, расположенный в западной части страны на острове Хонсю. В настоящее время в регион входит семь префектур: Вакаяма, Киото, Миэ, Нара, Осака, Сига и Хёго [Nihei 2018: 6]. На территории региона Кинки обнаружено свыше 750 крупных кофун. Именно в регионе Кансай располагался центр культуры Кофун; здесь можно увидеть наиболее крупные курганы Японии.

МИЩЕНКОВА Мария Сергеевна - магистрант 2-го года обучения исторического факультета Федерального государственного бюджетного образовательного учреждения высшего образования Иркутский государственный университет (г. Иркутск, Россия). E-mail: markuz97@mail.ru. 
Политический центр государства Ямато находился в регионе Кинки, в связи с этим здесь обнаружено большое скопление курганов (рис. 1). Они могли возникать в местах, где поколениями хоронили членов знатных родов и кланов; с другой стороны, некоторые скопления, характерными особенностями которых были гигантские размеры и преобладание курганов в форме «замочной скважины» (дзэнпо:ко:энфун), являются местами захоронений правителей государства Ямато и членов императорской семьи.

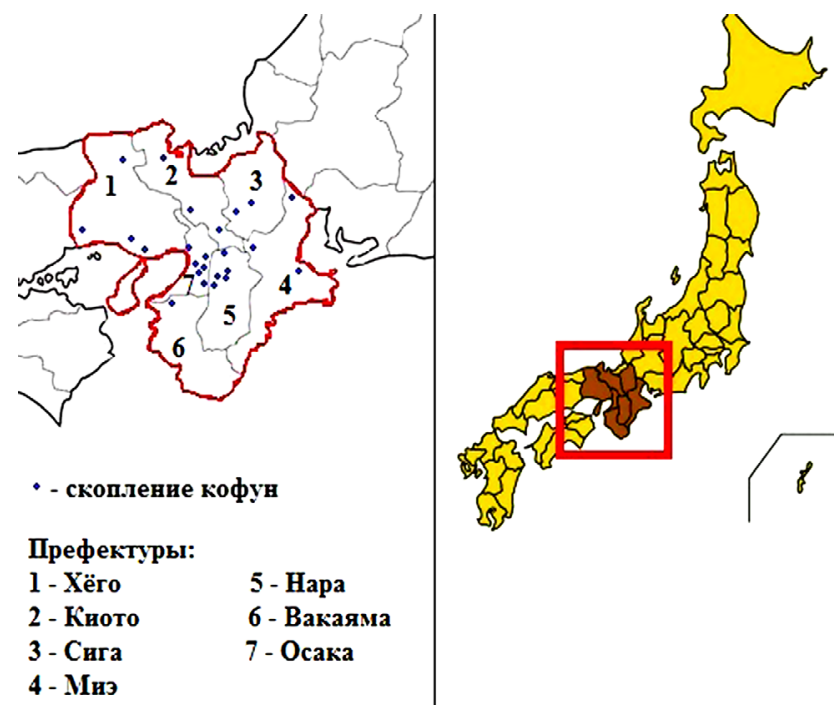

Рис. 1. Скопления курганов в регионе Кинки

В префектуре Вакаяма расположено крупное скопление курганов - Ивасэс эн представляющее собой группу из 800 кофун, из которых хорошо сохранилось около половины. Строительство их началось в V в. и достигло своего расцвета в VI в. [Кофун дзидай-но кэнкю: 1990: 154]. Крупнейшие кофун в Ивасэсэндзука-кофун-гун имеют форму замочной скважины и построены во 2-й половине VI в.: Сё:гундзука-кофун (длина - 42,5 м), Тидзидзука-кофун $(34,5$ м), Гунтё: дзука-кофун (30,5 м) [Ивасэс эн д з у ка - ко фу н - гун н . Распределение по формам среди хорошо сохранившихся 469 кофун было следующим: круглых (энфун) 437 курганов $(93,2 \%)$, в форме замочной скважины (дзэнпо:ко:энфун) - 16 курганов $(3,4$ \%), квадратных (хо:фун) - 4 (0,9 \%), неясной формы - 12 кофун (2,6 \%) [Ооцука и др. 1989: 65]. Преобладание курганов круглой формы и их большое количество предполагает наличие чрезвычайно сильных политических связей на территории современной префектуры Вакаяма в V-VI вв.

Префектура Нара наряду с префектурой Осака - одна из самых «богатых» в Японии по количеству и размерам кофун. Именно здесь, как предполагают исследователи, шел процесс выделения формы курганов дзэнпо:ко:энфун - в форме замочной скважины, что встречается только на японских островах. На территории префектуры Нара кофун возводились в течение всего периода культуры Кофун. Одно из ранних скоплений, датируемое III в., находится на юго-востоке долины Нара в г. Сакураи - Макимуку-кофун-гун. Курганы данного скопления, несмотря на то, что были построены на самом начальном этапе формирования культуры Кофун, имеют форму «замочной скважины» и внушительные для III в. размеры (длиной до 120 м) [Там же: 532]. В г. Сакураи есть еще одно небольшое скопление курганов позднего периода культуры Кофун - Тамасаяма-кофун-гун, состоящее из трех небольших курганов дзэнпо:ко:энфун, построенных во 2-й половине VI в. (табл. 1).

В северной части префектуры Нара находится одно из крупнейших скоплений


гун считаются местами захоронения японских императоров, правивших в средний период Кофун (все императорские курганы в данной местности датированы 2-й 
половиной IV - 1-й половиной V в.). Скопление не оставляет никаких сомнений в том, где находился политический и культурный центр государства Ямато в IVV вв. [Кофун дзидай-но кэнкю: 1990: 133, 138].

Таблица 1

Курганы Тамасаяма-кофун-гун

\begin{tabular}{|l|c|c|c|c|c|c|}
\hline \multicolumn{1}{|c|}{ Курган } & $\begin{array}{c}\text { Длина, } \\
\text { м }\end{array}$ & $\begin{array}{c}\text { Диаметр } \\
\text { круглой } \\
\text { части, м }\end{array}$ & $\begin{array}{c}\text { Высота } \\
\text { круглой } \\
\text { части, м }\end{array}$ & $\begin{array}{c}\text { Ширина } \\
\text { трапециевид- } \\
\text { ной части, м }\end{array}$ & $\begin{array}{c}\text { Высота } \\
\text { трапециевид- } \\
\text { ной части, м }\end{array}$ & $\begin{array}{c}\text { Время } \\
\text { постройки }\end{array}$ \\
\hline $\begin{array}{l}\text { Тамасаяма- } \\
\text { кофун (1) }\end{array}$ & 45 & 22 & 5 & 22 & 5 & 2-я пол. VI в. \\
\hline $\begin{array}{l}\text { Тамасаяма- } \\
\text { кофун (2) }\end{array}$ & 75 & 40 & $\begin{array}{c}\text { Нет } \\
\text { данных }\end{array}$ & 40 & Нет данных & 2-я пол. VI в. \\
\hline $\begin{array}{l}\text { Тамасаяма- } \\
\text { кофун (3) }\end{array}$ & 47,5 & 25 & 5 & 25 & 3 & 2-я пол. VI в. \\
\hline
\end{tabular}

Строительство столь больших курганов, состоящих из нескольких ярусов и окруженных двумя-тремя рвами и тысячами ханива (полых глиняных фигурок), требовало значительных затрат и большого количества рабочей силы. В строительстве императорских курганов в это время прослеживается некая «гигантомания», имевшая целью утвердить роль императора и его социальный статус. Местные кланы с периферии, несмотря на большое влияние на местах, не имели возможности строить даже для самых важных членов клана такие гигантские захоронения. Масштабы курганов можно оценить, ознакомившись с основными измерениями (табл. 2) [Ооцука и др. 1989: 52, 86-87, 237, 485]. Данные варьируются в зависимости от источника в пределах 1-2 м.

Таблица 2

Крупнейшие курганы Саки-кофун-гун

\begin{tabular}{|c|c|c|c|c|c|c|}
\hline Курган & $\begin{array}{c}\text { Длина, } \\
\text { м }\end{array}$ & $\begin{array}{l}\text { Диаметр } \\
\text { круглой } \\
\text { части, м }\end{array}$ & $\begin{array}{l}\text { Высота } \\
\text { круглой } \\
\text { части, м }\end{array}$ & $\begin{array}{c}\text { Ширина } \\
\text { трапециевид- } \\
\text { ной части, м }\end{array}$ & $\begin{array}{c}\text { Высота } \\
\text { трапециевид- } \\
\text { ной части, м }\end{array}$ & $\begin{array}{c}\text { Время } \\
\text { постройки }\end{array}$ \\
\hline Госаси-кофун & 275 & 195 & 23 & 155 & 27 & $\begin{array}{l}\text { 2-я пол. IV } \\
\text { - нач. V в. }\end{array}$ \\
\hline $\begin{array}{l}\text { Сакиисидзу- } \\
\text { каяма-кофун }\end{array}$ & 218 & 132 & 19 & 111 & 16 & $\begin{array}{c}\text { 2-я пол. IV } \\
\text { - 1-я пол. } \\
\text { V в. }\end{array}$ \\
\hline $\begin{array}{l}\text { Сакимиса- } \\
\text { сагияма- } \\
\text { кофун } \\
\end{array}$ & 206 & 130 & 18 & 89 & 12,3 & $\begin{array}{c}\text { 2-я пол. IV } \\
\text { - 1-я пол. } \\
\text { V в. }\end{array}$ \\
\hline $\begin{array}{l}\text { Итинива- } \\
\text { кофун }\end{array}$ & 253 & 150 & 11 & 160 & 11 & $\begin{array}{c}\text { 1-я пол. } \\
\text { V в. }\end{array}$ \\
\hline $\begin{array}{l}\text { Хисиагэ- } \\
\text { кофун }\end{array}$ & 219 & 124 & 16,2 & 145 & 13,6 & $\begin{array}{l}\text { Cер. - 2-я } \\
\text { пол. V в. }\end{array}$ \\
\hline $\begin{array}{l}\text { Уванабэ- } \\
\text { кофун }\end{array}$ & 256 & 129 & 20 & 127 & 20 & Cep. V в. \\
\hline Конабэ-кофун & 204 & 125 & 20 & 129 & 17,5 & $\begin{array}{c}\text { 1-я пол. } \\
\text { V в. }\end{array}$ \\
\hline
\end{tabular}




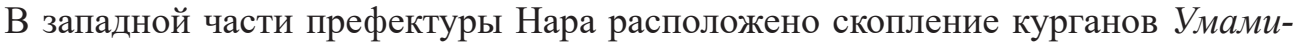
кофун-гун (рис. 2). Строительство кофун в этой местности относится ко 2-й половине IV - началу VI в. н. э. В Умами-кофун-гун есть курганы длиной более 200 м; почти все крупные курганы здесь имеют форму замочной скважины [Ооцука и др. 1989: 84-85]. При этом древнейший курган в данном скоплении - Синъямакофун имеет квадратную форму (дзэнпо:ко:хо:фун), длину 126 м, ширину 66-67 м, высоту от 6 до 10 м. Данные о размерах шести крупнейших кофун Умами-кофунгун в форме замочной скважины, представленные в таблице 3 , дают представление о масштабах строительства в этой местности в средний период культуры Кофун [Там же: 187, 378].

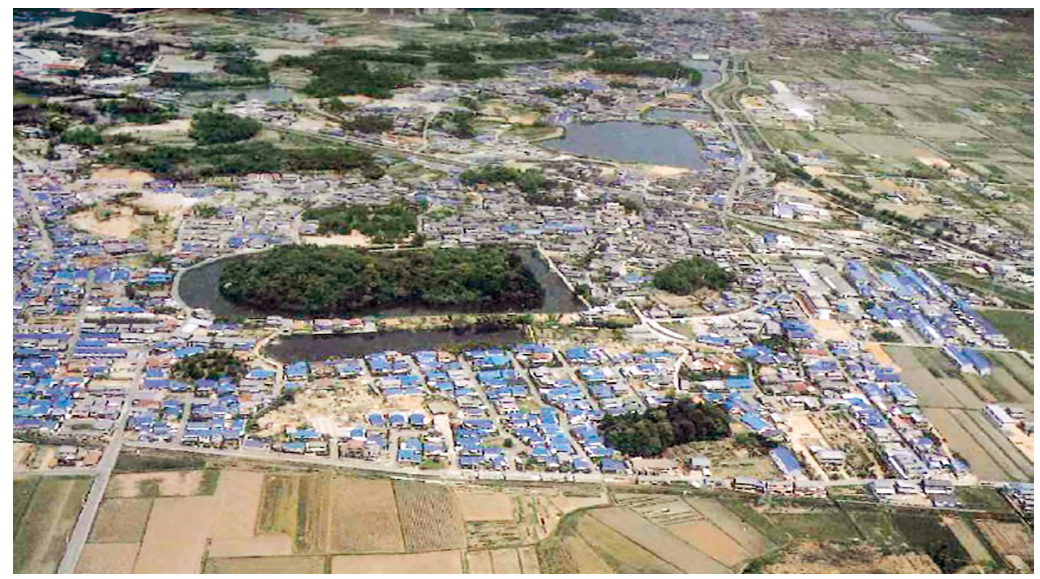

Рис. 2. Скопление курганов Умами-кофун-гун, преф. Нара

Таблица 3

Крупнейшие курганы Умами-кофун-гун

\begin{tabular}{|l|c|c|c|c|c|c|}
\hline \multicolumn{1}{|c|}{ Курган } & $\begin{array}{c}\text { Длина, } \\
\text { м }\end{array}$ & $\begin{array}{c}\text { Диаметр } \\
\text { круглой } \\
\text { части, м }\end{array}$ & $\begin{array}{c}\text { Высота } \\
\text { круглой } \\
\text { части, м }\end{array}$ & $\begin{array}{c}\text { Ширина } \\
\text { трапециевид- } \\
\text { ной части, м }\end{array}$ & $\begin{array}{c}\text { Высота } \\
\text { трапециевид- } \\
\text { ной части, м }\end{array}$ & $\begin{array}{c}\text { Время } \\
\text { постройки }\end{array}$ \\
\hline $\begin{array}{l}\text { Самитатакара- } \\
\text { дука-кофун }\end{array}$ & 111,5 & 60 & 8 & 45 & 8 & $\begin{array}{c}\text { 2-я пол. } \\
\text { IV в. }\end{array}$ \\
\hline Суяма-кофун & 220 & 130 & 19 & 112 & 16 & $\begin{array}{c}\text { Конец IV } \\
\text { нач. V в. }\end{array}$ \\
\hline Цукияма-кофун & 210 & 120 & $\begin{array}{c}\text { Нет } \\
\text { данных }\end{array}$ & 105 & Нет данных & $\begin{array}{c}\text { 2-я пол. - } \\
\text { кон. IV в. }\end{array}$ \\
\hline Никияма-кофун & 200 & 117 & 19 & 115 & 17 & $\begin{array}{c}\text { 1-я пол. } \\
\text { V в. }\end{array}$ \\
\hline $\begin{array}{l}\text { Каваиооиукая- } \\
\text { ма-кофун }\end{array}$ & 197 & 108 & 15,8 & 110 & 16,4 & $\begin{array}{c}\text { Сер. - } \\
\text { конец V в. }\end{array}$ \\
\hline $\begin{array}{l}\text { Кицуисирояма- } \\
\text { кофун }\end{array}$ & 140 & 90 & $\begin{array}{c}\text { Нет } \\
\text { данных }\end{array}$ & 110 & Нет данных & $\begin{array}{c}\text { Конец V - } \\
\text { нач. VI в. }\end{array}$ \\
\hline
\end{tabular}

Как видно из таблицы 3, крупные (более 110 м в длину) дзэнпо:ко:энфун в этом районе возводились постепенно со 2-й половины IV по начало VI в. В данных курганах хоронили представителей влиятельного клана Кацураги, имевшего большое влияние в государстве Ямато в период строительства курганов Умами-ко$ф у н-г у н$. 
Археология

Недалеко от Умами-кофун-гун расположено скопление Кубико-кофун-гун, датируемое началом VI - серединой VII в. Кубико-кофун-гун - скопление из 10 курганов, из которых только один - в форме замочной скважины; остальные - 6 энфун и 3 хо:фунн [Кубико-кофун-гун].

Можно сделать вывод, что строительство кофун на территории префектуры Нара достигло своего апогея в IV-V вв.; после этого традиции строительства курганов понемногу начинают уходить в прошлое. В поздний период культуры Кофун мы встречаем на данной местности только небольшие скопления кофун, размеры которых, по сравнению с гигантскими захоронениями в Саки-кофун-гун, очень невелики. В то же время погребальный инвентарь даже в таких небольших курганах продолжает быть весьма богатым: металлические шары, бусины, золотые и бронзовые полые инкрустации, железные мечи, конское снаряжение, глиняная посуда типов суэки и хадзики [Ооцука и др. 1989: 351].

В префектуре Хёго не увидеть таких масштабных скоплений курганов, как в префектурах Нара и Осака. Относительно центра культуры Кофун: рассматриваемая территория находилась на периферии, поэтому здесь не было большого количества влиятельных кланов. В то же время находки из курганов префектуры Хёго и особенности организации погребальных камер говорят о влиянии континента.

В г. Кобе есть небольшое скопление курганов Тэнно:дзан-кофун-гун, построенных в период с 1-й половины IV до начала VI в. В Тэнно:дзан-кофун-гун есть курган редкой формы - хотатегайкей-кофун, в виде гребешка. Этот курган был построен в 1-й половине IV в.; форма гребешка, как полагают ученые, позже могла трансформироваться в дзэнпо:ко:энфун. Погребальный инвентарь не такой богатый, как в Осаке или Наре, - стеклянные шары, железное оружие, керамика [Там же: 395].

На восточном берегу верхнего течения р. Какогава локализуется скопление Сайдзё:-кофун-гун, относящееся к среднему периоду культуры Кофун (V-VI вв.). Состоящее из десятка курганов скопление включает в себя три крупных кофун, например Гё:дзядзука-кофун, построенное в 1-й половине V в. Длина кургана в форме замочной скважины достигает 100 м; он построен в 3 яруса и окружен рвом с максимальной шириной 14 м. В нем были найдены одни из старейших в Японии изделия из золота и бронзы [Там же: 247].

К числу поздних скоплений курганов относится Ооябу-кофун-гун в префектуре Хёго, находящийся на северном берегу р. Маруяма и состоящий из небольших круглых и квадратных курганов с максимальным диаметром 35 м. Все курганы построены во 2-й половине VI - 1-й половине VII в.

Камиоотани-кофун-гун находится недалеко от г. Дзёё (префектура Киото), на холмах Камиоотани. Это достаточно небольшое скопление кофун, однако курганы в этой местности возводились в течение всего периода Кофун (с 1-й половины III по 1-ю половину VII в.). Среди сохранившихся курганов 2 в форме замочной скважины, 8 - квадратной формы и 9 - круглой формы. Несмотря на небольшие размеры кофун (максимальная длина - 30 м, ширина круглых и квадратных курганов в среднем 10-15 м), при раскопках был найден разнообразный погребальный инвентарь, в т. ч. бронзовые зеркала, железные мечи и другие изделия из железа, изогнутые бусины магатама, ханива в форме водоплавающих птиц и домов [Там же: 161].

Цукурияма-кофун-гун - скопление курганов в г. Ёсано (на северо-западе префектуры Киото), датированное концом IV - началом V в. Для префектуры Киото характерно сочетание разнообразных форм курганов в одном скоплении. В данном случае здесь два квадратных (со средней стороной 16 м), два круглых (диаметром 30-35 м) и два квадратно-круглых (в форме замочной скважины) кофун. 
Крупнейший курган в этом скоплении - Эбисуяма-кофун (cep. IV в.) имеет форму дзэнпо:ко:энфун, длину около 145 м, диаметр круглой части 100 м, высоту круглой части 16 м, ширину трапециевидной части 62 м и высоту трапециевидной части 11 м. Кофун в виде замочной скважины в Цукурияма-кофун-гун облицованы каменной кладкой. Среди погребального инвентаря в основном встречаются бронзовые зеркала, каменное и железное оружие [Ооцука и др. 1989: 380].

Интересное по формам курганов скопление Тё:хо:дзинанацудзука-кофун-гун находится в г. Нагаокакё (префектура Киото). До нашего времени сохранилось всего четыре кургана этой группы, все построены в поздний период культуры Кофун и имеют небольшой размер. Три кофун имеют квадратную форму, а один форму гребешка (хотатегайкей-кофун) [Тё:хо:дзинанацудзука-кофун-гун]. Нужно отметить, что квадратные курганы гораздо чаще встречаются в скоплениях в западной части региона Кинки. Это объясняется влиянием культуры провинции Идзумо, которая находилась западнее Кинки на побережье Японского моря [Кофун дзидай-но кэнкю: 1990: 144-145].

В префектуре Осака есть несколько крупных скоплений курганов. Скопление Итисука-кофун-гун, расположенное в районе Кавати на востоке префектуры Осака, включает в себя порядка 280 кофун; большинство курганов имеют круглую форму и диаметр от 8 до 20 м [Итисука-кофун-гун]. Погребальный инвентарь состоит из металлических изделий: железных и бронзовых мечей, зеркал, элементов конской упряжи. Найденные образцы миниатюрных металлических заколок для волос говорят о континентальном влиянии (со стороны Китая либо Кореи) [Ооцука и др. 1989: 51$]$.

В этой же префектуре находятся два скопления с невероятно большими курганами, крупнейшими в Японии, - это Фуруити-кофун-гун и Модзу-кофун-гун, первое - на юго-востоке префектуры (рис. 3). В скоплении - более 100 курганов, самые крупные имеют форму замочной скважины [Мори 1984: 60-61]. Все курганы этой группы построены в IV-V вв., крупные курганы окружены рвами (от 1 до 3), насыпями, имеют многоярусную структуру, окружены тысячами глиняных фигурок ханива как цилиндрической формы, так и в виде животных, птиц, людей и домов [Кофун дзидай-но кэнкю: 1990: 125].

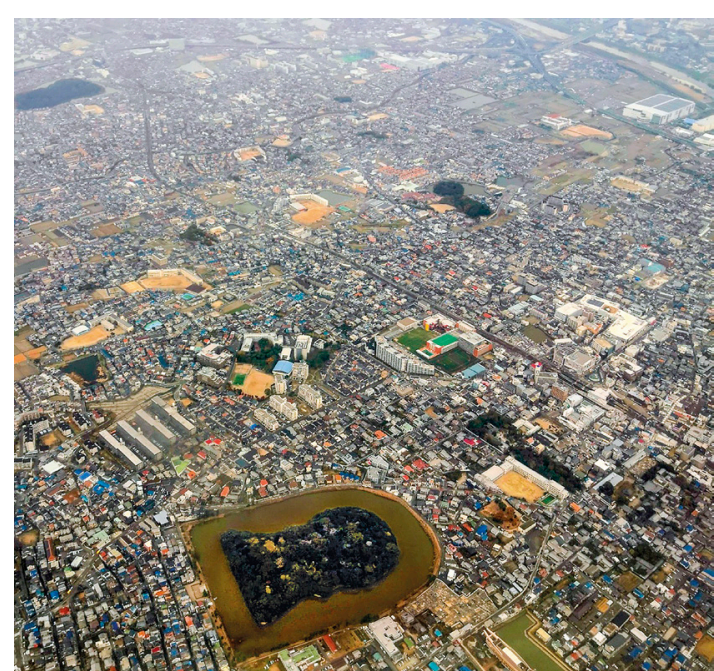

Рис. 3. Кофун в префектуре Осака. Вид с воздуха

Из таблицы 4 видно, что пик «гигантомании» в строительстве ко$ф у н$ в префектуре Осака совпадает с ситуацией в префектуре Нара, что немудрено: крупнейшие скопления IV-VI вв. находятся на сравнительно небольшом расстоянии, и все они близки к политическому центру государства Ямато [Итиносе 2016: 24]. В связи с этим рассмотрим еще одно крупное скопление (в прежние времена в него входило до 100 курганов, сейчас в силу хозяйственного освоения территории осталось около 40).

Модзу-кофун-гун находится в северной части г. Сакаи префектуры Осака. Совместно с рассмотренным выше Фуруити-кофун-гун в 2019 г. оно вошло в список объектов Всемирного 
культурного наследия ЮНЕСКО. Время строительства курганов Модзу-кофун-гунвсе тот же период «гигантомании», с конца IV по начало V в. Как и в большинстве крупных курганов, в Фуруити-кофун-гун и Модзу-кофун-гун хоронили императоров и членов императорской семьи, в связи с чем существует запрет на проведение раскопок данных кофун (в Японии по сей день правит та же императорская династия, что и в период Кофун, и охрана покоя предков - одна их важнейших задач при сохранении курганов данных скоплений). В Модзу-кофун-гун входит самый большой курган в Японии - кофун императора Нинтоку [Кофун дзидай-но кэнкю: 1990: 128-129]. Помимо него есть еще несколько довольно крупных (длиной более 100 м) курганов, все они выполнены в форме замочной скважины (табл. 5) [Мори 1984: 36-37, 85].

Таблица 4

Крупнейшие курганы Фуруити-кофун-гун

\begin{tabular}{|c|c|c|c|c|c|c|}
\hline Курган & $\begin{array}{c}\text { Длина, } \\
\text { м }\end{array}$ & $\begin{array}{l}\text { Диаметр } \\
\text { круглой } \\
\text { части, м } \\
\end{array}$ & $\begin{array}{l}\text { Высота } \\
\text { круглой } \\
\text { части, м }\end{array}$ & $\begin{array}{c}\text { Ширина } \\
\text { трапециевид- } \\
\text { ной части, м }\end{array}$ & $\begin{array}{c}\text { Высота } \\
\text { трапециевид- } \\
\text { ной части, м }\end{array}$ & $\begin{array}{c}\text { Время } \\
\text { постройки }\end{array}$ \\
\hline $\begin{array}{l}\text { Комурояма- } \\
\text { кофун }\end{array}$ & 150 & 96 & 15,3 & 100 & 9,3 & $\begin{array}{l}\text { 1-я пол. } \\
\text { V в. }\end{array}$ \\
\hline $\begin{array}{l}\text { Цудо:сиро- } \\
\text { яма-кофун }\end{array}$ & 208 & 128 & 17 & 120 & 13 & $\begin{array}{c}\text { 2-я пол. } \\
\text { IV в. }\end{array}$ \\
\hline $\begin{array}{l}\text { Нонакамия- } \\
\text { яма-кофун }\end{array}$ & 154 & 100 & 14,1 & 75 & 10,1 & $\begin{array}{c}\text { 1-я пол. } \\
\text { V в. }\end{array}$ \\
\hline $\begin{array}{l}\text { Накаиуяма- } \\
\text { кофун }\end{array}$ & 290 & 170 & 26 & 19,3 & 23 & $\begin{array}{c}\text { 1-я пол. } \\
\text { V в. }\end{array}$ \\
\hline $\begin{array}{l}\text { Хакаяма- } \\
\text { кофун }\end{array}$ & 225 & 135 & 21 & 153 & 19 & $\begin{array}{c}\text { 1-я пол. } \\
\text { V в. }\end{array}$ \\
\hline $\begin{array}{l}\text { Кондагобё: } \\
\text { яма-кофуун }\end{array}$ & 425 & 250 & 35 & 300 & 36 & $\begin{array}{c}\text { 1-я пол. } \\
\text { V в. }\end{array}$ \\
\hline $\begin{array}{l}\text { Итинояма- } \\
\text { кофун }\end{array}$ & 230 & 140 & 22,3 & 160 & 23,3 & Cep. V в. \\
\hline $\begin{array}{l}\text { Карусато- } \\
\text { ооиука- } \\
\text { кофун } \\
\end{array}$ & 200 & 106 & 20 & 165 & 23 & $\begin{array}{c}\text { 2-я пол. } \\
\text { V в. }\end{array}$ \\
\hline $\begin{array}{l}\text { Окамисан- } \\
\text { дзай-кофун }\end{array}$ & 242 & 148 & 19,5 & 182 & 16 & $\begin{array}{c}\text { 2-я пол. } \\
\text { V в. }\end{array}$ \\
\hline $\begin{array}{l}\text { Такаясиро- } \\
\text { яма-кофун }\end{array}$ & 122 & 78 & 13 & 100 & 13 & $\begin{array}{c}\text { 1-я пол. } \\
\text { VI в. }\end{array}$ \\
\hline
\end{tabular}

Таблица 5

Крупнейшие курганы Модзу-кофун-гун

\begin{tabular}{|c|c|c|c|c|c|c|}
\hline \multicolumn{1}{|c|}{ Курган } & $\begin{array}{c}\text { Длина, } \\
\text { м }\end{array}$ & $\begin{array}{c}\text { Диаметр } \\
\text { круглой } \\
\text { части, м }\end{array}$ & $\begin{array}{c}\text { Высота } \\
\text { круглой } \\
\text { части, м }\end{array}$ & $\begin{array}{c}\text { Ширина } \\
\text { трапециевид- } \\
\text { ной части, м }\end{array}$ & $\begin{array}{c}\text { Высота } \\
\text { трапециевид- } \\
\text { ной части, м }\end{array}$ & $\begin{array}{c}\text { Время } \\
\text { постройки }\end{array}$ \\
\hline 1 & 2 & 3 & 4 & 5 & 6 & 7 \\
\hline Дайсен-кофун & 486 & 249 & 35,8 & 307 & 33,9 & $\begin{array}{c}\text { 1-я пол. - } \\
\text { сер. V в. }\end{array}$ \\
\hline $\begin{array}{l}\text { Камиисидзуми- } \\
\text { сандзай-кофун }\end{array}$ & 365 & 205 & 28 & 235 & 25 & $\begin{array}{c}\text { 1-я пол. } \\
\text { V в. }\end{array}$ \\
\hline
\end{tabular}


Окончание табл. 5

\begin{tabular}{|l|c|c|c|c|c|c|}
\hline 1 & 2 & 3 & 4 & 5 & 6 & 7 \\
\hline Гобё:яма-кофун & 186 & 95 & 17 & 119 & 17 & $\begin{array}{c}\text { 2-я пол. } \\
\text { V в. }\end{array}$ \\
\hline $\begin{array}{l}\text { Хадзенисандзай- } \\
\text { кофун }\end{array}$ & 290 & 156 & 24 & 226 & 22,5 & Сер. V в. \\
\hline Тадеияма-кофун & 148 & 76 & 14 & 110 & 15 & $\begin{array}{c}\text { 2-я пол. } \\
\text { V в. }\end{array}$ \\
\hline Итасуке-кофун & 146 & 90 & 12 & 99 & 11 & Сер. V в. \\
\hline
\end{tabular}

Как видим, самый крупный кофун относится к скоплению Модзу-кофун-гун, однако большинство курганов длиной более 150 м все же находятся в другом скоплении - Фуруити-кофун-гун. В Модзу-кофун-гун более очевиден контраст между тремя крупнейшими кофун и остальными, в то время как в Фуруитикофун-гун размер курганов уменьшается более плавно. Так или иначе, крупнейшие скопления курганов, включающие гигантские захоронения правителей государства Ямато, сосредоточены в трех основных скоплениях - Фуруити-кофун-гун, Модзу-

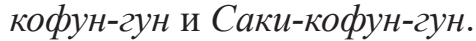

Небольшое скопление (порядка 40 курганов) Сакурадзука-кофун-гун находится в северо-западной части префектуры Осака, в г. Тоёнака. Все курганы данного скопления были построены в средний период культуры Кофун (датированы концом V - концом VI в.). В Сакурадзука-кофун-гун три кургана имеют форму замочной скважины, остальные - круглые. Большинство кофун в данном скоплении было окружено рвами и имело многоярусное строение [Сакурадзука-кофун-гун]. Похоже, в данных курганах хоронили высокопоставленных военных: кофун достигают в длину до 80 м, а отличительной особенностью погребального инвентаря является заметное преобладание в нем оружия, доспехов и конской упряжи, выполненных из железа и бронзы. Часть курганов были облицованы каменной кладкой и окружены рядами ханива [Ооцука и др. 1989: 254-255].

Префектура Миэ находится на приличном расстоянии от долины Нара, где была сосредоточена жизнь древнеяпонского государства. К сожалению, даже те немногие скопления курганов, которые все же были возведены на востоке Кансая, были почти полностью уничтожены в ходе хозяйственного освоения и заселения земель. Например, по данным исследований 1928 г., в скоплении Такарадзука-кофун-гун (г. Мацусака) насчитывалось 88 курганов. Однако в настоящее время можно увидеть только 3 из них - 1 энфун и 2 дзэнпо:ко:энфун, датированные V в. н. э. В сравнении с курганами, которые возводились в этот период на территории префектур Нара и Осака, кофун префектуры Миэ небольшие (табл. 6) [Там же: 340].

Таблица 6

Курганы Такарадзука-кофун-гун

\begin{tabular}{|l|c|c|c|c|c|c|}
\hline \multicolumn{1}{|c|}{ Курган } & $\begin{array}{c}\text { Длина, } \\
\text { м }\end{array}$ & $\begin{array}{c}\text { Диаметр } \\
\text { круглой } \\
\text { части, м }\end{array}$ & $\begin{array}{c}\text { Высота } \\
\text { круглой } \\
\text { части, м }\end{array}$ & $\begin{array}{c}\text { Ширина } \\
\text { трапециевид- } \\
\text { ной части, м }\end{array}$ & $\begin{array}{c}\text { Высота } \\
\text { трапециевид- } \\
\text { ной части, м }\end{array}$ & $\begin{array}{c}\text { Время } \\
\text { постройки }\end{array}$ \\
\hline $\begin{array}{l}\text { Такарадзука- } \\
\text { кофун (1) }\end{array}$ & 95 & 54 & 7,8 & 54 & 4,8 & $\begin{array}{c}\text { 1-я пол. } \\
\text { V в. }\end{array}$ \\
\hline $\begin{array}{l}\text { Такарадзука- } \\
\text { кофун (2) }\end{array}$ & 72 & 60 & 8,25 & 34 & $0,6-1,5$ & Конец V в. \\
\hline
\end{tabular}


Археология

На северо-западе префектуры Миэ находится скопление Muхата-кофунгун, интересное с точки зрения разнообразия форм (здесь есть как кофун в виде замочной скважины и гребешка, так и энфун и хо:фун). Курганы Muхата-кофунгун были построены в период с конца IV по 2-ю половину VI в., имели достаточно крупный для кофун размер - построенные на периферии в длину достигали 142 м [Ооцука и др. 1989: 560].

Как и в Миэ, в префектуре сига не наблюдается многочисленных крупных скоплений курганов. Минамигаса-кофун-гун - скопление, в которое входило до 22 кофун, находится на юго-западе префектуры Сига. Основная форма дзэнпо:ко:энфун, однако курганы, по сравнению с императорскими в префектурах Нара и Осака, здесь совсем крошечные (длиной до 30 м) и были построены с большой разницей во времени (в целом скопление датируется V-VI вв.) [Там же: $556]$.

В центральной части префектуры Сига на холмах Ооиваяма располагается одноименное скопление курганов Ооиваяма-кофун-гун [Там же: 99]. Кофун строили здесь на протяжении нескольких веков (со 2-й половины III по VI в.), в связи с чем здесь встречаются сразу четыре их формы: квадратноквадратные, квадратно-круглые (в виде замочной скважины), круглые и в виде гребешка [Ооиваяма-кофун-гун]. Судя по всему, в этой местности на протяжении всего периода Кофун хоронили людей из одного знатного рода.

На основании всего вышесказанного можно заключить, что наиболее активное строительство кофун, в т. ч. Очень больших, происходило на территории современных префектур Нара и Осака. В то же время скопление курганов по периферии указывает на наличие прочных политических связей между местными кланами и государством Ямато по всему региону Кинки.

Размеры курганов в скоплениях Фуруити-кофун-гун и Модзу-кофун-гун говорят о высоком уровне развития производственных сил, наличии большого количества рабочей силы в государстве Ямато. Император изначально играл в древнеяпонском государстве важную роль, и в укреплении его авторитета и места в обществе определенную роль сыграли именно императорские курганы, которые до сих пор считаются священными и неприкосновенными местами. Изучение скоплений курганов поможет лучше понять структуру древнеяпонского общества, особенности социально-экономических связей между регионами и центром государства Ямато. Не менее важны различия в наборе погребального инвентаря и оформлении курганов в разных местностях, свидетельствующие не только о внешнем влиянии, но и о внутренних процессах формирования культуры Кофун.

\section{Аитература}

Ивасэсэндзука-кофун-гун [Электронный ресурс] // Кофун-маппу [Карта кофун]. Режим доступа: https://kofun.info/kofun/21 (на яп. яз).

Итиносэ K. Модзу-Фуруити-кофун-гун. Хигаси адзиа-но нака-нокё:дай кофун-гун [Скопления кофун Модзу и Фуруити. Крупнейшие скопления курганов в Восточной Азии] / Кадзуо Итиносэ. - Токио: Доусэйся, 2016. - 144 с. (на яп. яз).

Итисука-кофун-гун [Электронный ресурс] // Кофун-маппу [Карта кофун]. - Режим доступа: https://kofun.info/kofun/6093 (на яп. яз).

Кофун дзидай-но кэнкю: [Исследования периода Кофун]: в 13 т. Т. 7: Функю: то наибуко:дзо [Курганы и их внутреннее устройство]. - Токио: Ю:дзанкаку сюппан, 1992. 157 с. (на яп. яз).

Кофун дзидай-но кэнкю: [Исследования периода Кофун]: в 13 т. Т. 10: Чиики-но кофун. Ниси нихон [Территориальные курганы. Западная Япония]. - Токио: Ю:дзанкаку сюппан, 1990. - 198 с. (на яп. яз). 
Кубико-кофун-гун [Электронный ресурс] // Кофун-маппу [Карта кофун]. - Режим доступа: https://kofun.info/kofun/1183 (на яп. яз).

Мори К. Кофун-дзидай [Эпоха Кофун]: в 3 т. Т. 2. Кинки / К. Мори. - Токио: Сякайсисо:ся, 1984. - 298 с. (на яп. яз.).

Ооиваяма-кофун-гун [Электронный ресурс] // Кофун-маппу [Карта кофун]. - Режим доступа: https://kofun.info/kofun/558 (дата обращения: 26.02.2021).

Ооиука X. Нихон кофун дайдзитен [Большой словарь японских курганов] // Х. Ооцука, С. Кобаяси, М. Кумано. - Токио: Токё:до:сюппан, 1989. - 639 с. (на яп. яз).

Сакурадзука-кофун-гун [Электронный ресурс] // Тоёнака-си [Город Тоёнака]. - Режим доступа: https://www.city.toyonaka.osaka.jp/jinken_gakushu/bunkazai/shitei_bunkazai/kinenbutsu/shiseki/shiseki001.html (на яп. яз).

Тё:хо:дзинанацудзука-кофун-гун [Электронный ресурс] // Кофун-маппу [Карта кофун]. - Режим доступа: https://kofun.info/kofun/3968 (на яп. яз).

Nihei T. The Regional Geography of Japan / T. Nihei. - Sapporo: Hokkaido University Press, 2018. $-251 \mathrm{p}$.

\section{References}

Ivasesendzuka-kofun-gun [Elektronnyj resurs] // Kofun-mappu [Karta kofun]. - Rezhim dostupa: https://kofun.info/kofun/21 (na yap. yaz).

Itinose K. Modzu-Furuiti-kofun-gun. Higasi adzia-no naka-nokyo:daj kofun-gun [Skopleniya kofun Modzu i Furuiti. Krupnejshie skopleniya kurganov v Vostochnoj Azii] / Kadzuo Itinose. Tokio: Dousejsya, 2016. - 144 s. (na yap. yaz).

Itisuka-kofun-gun [Elektronnyj resurs] // Kofun-mappu [Karta kofun]. - Rezhim dostupa: https://kofun.info/kofun/6093 (na yap. yaz).

Kofun dzidaj-no kenkyu: [Issledovaniya perioda Kofun]: v 13 t. T. 7: Funkyu: to naibuko:dzo [Kurgany $\mathrm{i}$ ih vnutrennee ustrojstvo]. - Tokio: Yu:dzankaku syuppan, 1992. - 157 s. (na yap. yaz).

Kofun dzidaj-no kenkyu: [Issledovaniya perioda Kofun]: v 13 t. T. 10: Chiiki-no kofun. Nisi nihon [Territorial'nye kurgany. Zapadnaya Yaponiya]. - Tokio: Yu:dzankaku syuppan, 1990. 198 s. (na yap. yaz).

Kubiko-kofun-gun [Elektronnyj resurs] // Kofun-mappu [Karta kofun]. - Rezhim dostupa: https://kofun.info/kofun/1183 (na yap. yaz).

Mori K. Kofun-dzidaj [Epoha Kofun]: v 3 t. T. 2. Kinki / K. Mori. - Tokio: Syakajsiso:sya, 1984. - 298 s. (na yap. yaz.).

Ooivayama-kofun-gun [Elektronnyj resurs] // Kofun-mappu [Karta kofun]. - Rezhim dostupa: https://kofun.info/kofun/558 (data obrashcheniya: 26.02.2021).

Oocuka H. Nihon kofun dajdziten [Bol'shoj slovar' yaponskih kurganov] // H. Oocuka, S. Kobayasi, M. Kumano. - Tokio: Tokyo:do:syuppan, 1989. - 639 s. (na yap. yaz).

Sakuradzuka-kofun-gun [Elektronnyj resurs] // Toyonaka-si [Gorod Toyonaka]. - Rezhim dostupa: https://www.city.toyonaka.osaka.jp/jinken_gakushu/bunkazai/shitei_bunkazai/kinenbutsu/shiseki/shiseki001.html (na yap. yaz).

Tyo:ho:dzinanacudzuka-kofun-gun [Elektronnyj resurs] // Kofun-mappu [Karta kofun]. Rezhim dostupa: https://kofun.info/kofun/3968 (na yap. yaz).

Nihei T. The Regional Geography of Japan / T. Nihei. - Sapporo: Hokkaido University Press, 2018. $-251 \mathrm{p}$. 